\title{
Role of Cytology in the Diagnosis and Management of HPV-Associated Head and Neck Carcinoma
}

\author{
Jeffrey F. Krane \\ Department of Pathology, Brigham and Women's Hospital and Harvard Medical School, Boston, Mass., USA
}

\section{Key Words}

Human papillomavirus · Oropharynx · Squamous cell carcinoma $\cdot$ Fine-needle aspiration

\begin{abstract}
Human papillomavirus (HPV)-associated head and neck squamous cell carcinoma (HNSCC) accounts for up to $25 \%$ of all HNSCCs. These tumors largely arise from the oropharynx, particularly the tonsil and base of tongue. The first manifestation of HPV-associated HNSCC is frequently as metastasis to cervical lymph nodes that can be documented by fineneedle aspiration. These metastases are often cystic with a predominantly non-keratinizing, basaloid morphology. Knowledge of the HPV status of metastatic HNSCC has significant treatment and prognostic implications as HPVassociated tumors have a more favorable prognosis than conventional HNSCC. Accordingly, HPV testing should be performed on any squamous cell carcinoma of unknown primary identified in neck lymph nodes. HPV detection may be performed using a variety of methods including $\mathrm{p} 16$ as a surrogate immunohistochemical marker, in situ hybridization and/or polymerase chain reaction detection of viral DNA or RNA. Further investigation is needed to determine the optimal method for HPV detection in fine-needle aspiration specimens. Cytology screening for HPV-associated HNSCC does not appear to be effective. Greater understanding of the natural history of oral HPV infections is needed before knowing if oral HPV testing may be useful as a screening test.

Copyright ๑ 2013 S. Karger AG, Basel
\end{abstract}

\section{KARGER}

Fax +41613061234

E-Mail karger@karger.com

www.karger.com
(C) 2013 S. Karger AG, Basel

0001-5547/13/0572-0117\$38.00/0

Accessible online at:

www.karger.com/acy

\section{Introduction}

The overall incidence of head and neck squamous cell carcinoma (HNSCC) in the United States has decreased along with the decline in cigarette smoking seen since the 1970s [1, 2]. Surprisingly, while the incidence of HNSCC has declined at most anatomic sites, oropharyngeal HNSCC has been increasing $[1,2]$ and now accounts for $20-25 \%$ of all HNSCCs [3, 4]. Similar trends have been noted in European nations as well [5]. These oropharyngeal carcinomas are now recognized as representing a clinically distinct variant of HNSCC resulting from infection with human papillomavirus (HPV) $[1-4,6]$.

Like conventional HNSCC, HPV-associated HNSCC occurs in men three times as frequently as women, but the $\mathrm{HPV}$-associated cancers differ in a number of other important respects [3, 5, 7-9]. HPV-associated HNSCC arises predominantly in the oropharynx (especially the tonsil and base of tongue). Patients are slightly younger than those with smoking-related HNSCC ( $<60$ vs. $>60$ years of age). HPV-associated HNSCC is most frequently associated with HPV type 16 in $85-90 \%$ of cases. Viral transmission is through sexual contact with sexual behavior-associated risk factors, such as the number of sexual partners, correlating with disease $[8,10]$. The precise sexual behaviors posing the greatest risk for viral transmission are not known. The male predominance of disease correlates with increased prevalence of oral infection by HPV type 16 in males [11] which may be due to the ease of female to male viral transmission via oral sex [12], 
hormonal factors [13] or immunologic factors [14, 15]. Cigarette smoking and marijuana use have also been implicated as risk factors $[8,11]$. At the cellular level, HPV-associated HNSCCs overexpress E6 and E7 viral oncoproteins. E6 expression promotes the loss of p53 protein while E7 inactivates the $\mathrm{Rb}$ protein product, which in turn leads to p16 overexpression $[16,17]$.

Of greatest clinical significance, HPV-associated HNSCC is associated with an improved prognosis relative to conventional HNSCC [18-27]. Since HPV-associated and conventional HNSCC are now recognized as clinically distinct entities, there is recognition that treatment should be optimized according to whether the tumor is HPV-associated or not. Newly formed clinical trials for HPV-associated HNSCC are largely focused on the concept of deintensified therapy [28]. Because of the responsiveness of HPV-associated HNSCC to conventional therapy, trials are being explored to use less intensive chemotherapy and/or radiotherapy to optimize clinical outcomes while simultaneously decreasing treatment-associated morbidity [28].

\section{Pathology}

The most common morphologic variant of HPV-associated HNSCC is that of a non-keratinizing, basaloid squamous cell carcinoma (SCC) $[3,29]$. This basaloid morphology should be distinguished from that seen in the clinically aggressive basaloid variant of HNSCC [30] that is non-HPV-related [31, 32]. Other histologic patterns have now been described in association with HPV infection including papillary SCC [33] and lymphoepithelial carcinoma-like tumors [34, 35]; however, these variants share the same favorable prognosis. Recently, small cell carcinoma of the oropharynx has been described as a rare morphologic variant of HPV-associated malignancy that is associated with poor clinical outcome, much like small cell carcinoma arising at other sites [36, 37].

Oropharyngeal HNSCCs, most of which are HPV-associated, commonly present with low $\mathrm{T}$-stage disease with small or even clinically occult primary tumors. Simultaneously, patients frequently have advanced $\mathrm{N}$-stage disease with cervical lymphadenopathy often being the presenting clinical finding [38]. Cervical lymph node metastases from HPV-associated HNSCC are often large in size and cystic in nature [39]. The cystic quality is sufficiently characteristic of these tumors that an HPV-associated oropharyngeal HNSCC should always be suspected in a patient with a cystic metastatic SCC in a cervical lymph node.

\section{Cytologic Diagnosis of HPV-Associated HNSCC}

\section{Screening for HPV-Associated HNSCC}

The concept of an oral Papanicolaou (Pap) test to screen for pre-invasive HPV-associated oropharyngeal HNSCC is appealing as a counterpart to the tremendous success of the Pap test as a screening tool for carcinoma of the uterine cervix. Unfortunately, both oral rinses and oral brushing specimens have failed at detecting squamous precursor lesions [40,41]. Although oral brushings may yield diagnostic material in patients with a tonsillar mass, oral rinses are not sensitive for malignancy even in the presence of a known malignancy [41]. There are several obstacles to an oropharyngeal Pap test equivalent. Unlike with cervical neoplasia, lesser degrees of dysplasia than carcinoma in situ have not been convincingly demonstrated for HPV-associated HNSCC. Anatomical limitations are likely to be the single most important factor preventing the successful development of an oral Pap test [42]. The base of tongue is inaccessible to sampling by oral brushing. Although the surface of the tonsil can be sampled by brush, HPV-associated disease largely develops in the tonsillar crypts. These extensive invaginations of the tonsillar epithelium are also not readily sampled by standard brushing techniques putting the sites where $\mathrm{HPV}$-associated disease arises out of reach of available sampling methods.

\section{Fine-Needle Aspiration Diagnosis of HPV-Associated HNSCC}

As indicated above, direct brushings of clinically apparent tonsillar masses can yield a diagnosis but are not used frequently in clinical practice [40, 41]. Fine-needle aspiration (FNA) also does not play a significant role in the diagnosis of HPV-associated HNSCC at the primary site due to the relative inaccessibility of the oropharynx and the often small size of the primary tumors.

Nevertheless, there is a significant role for cytology as the initial diagnostic modality for HPV-associated HNSCC. Since a majority of patients have cervical nodal metastatic disease as the initial manifestation of HPVassociated HNSCC, FNA is commonly the diagnostic method of choice for initial evaluation of such patients.

For any newly diagnosed metastatic SCC to a neck lymph node, determination of HPV status should now be a standard part of the cytologic work-up. Detection of HPV status in metastatic SCC is valuable for several reasons:

(1) Identification of Primary Site. Since the primary tumor in HPV-associated HNSCC is frequently occult, 
FNAs from the involved neck nodes of these patients are evaluated as a malignancy of unknown primary site. Identification of HPV in the metastatic deposit is generally indicative of an oropharyngeal primary [43]. This knowledge can facilitate a targeted endoscopic examination to identify a potentially subtle abnormality facilitating biopsy confirmation of the primary tumor. If the primary tumor is still not identified, tonsillectomy with complete histologic sampling may be appropriate to try to identify the primary.

(2) Guiding Directed Clinical Treatment. In 3-9\% of metastatic SCCs to the neck, a primary site cannot be identified despite extensive clinical, radiologic and pathologic evaluation [44]. In the absence of a known primary, all upper respiratory mucosa theoretically harboring an occult primary may be subjected to radiation therapy with the associated complications, including mucositis and xerostomia. In patients with no identifiable primary, presumptive localization of the primary site to the oropharynx based on positive HPV status allows directed radiation that spares the nasopharynx and significantly reduces patient morbidity.

(3) Prognosis and Clinical Trial Selection. As stated above, there is a favorable prognosis for HPV-associated HNSCC relative to conventional HNSCC [19-27]. Accordingly, clinical trials are being tailored to deintensified therapy for patients with HPV-associated HNSCC [28]. Novel therapies targeting the virus such as therapeutic HPV vaccines are also being investigated [45]. Conversely, for HPV-negative SCC, more intensive treatment protocols may be warranted.

(4) Distinction of New Primary SCC versus Metastatic Disease. Because SCCs arising from different sites exhibit marked morphologic and immunophenotypic overlap with one another, establishing the primary site based purely on cytologic appearance is generally not possible. It is worthwhile to compare the morphology of the current and previous tumor when the latter is available. Nevertheless, in most instances the morphological variability and overlap will be such that it will not be possible to offer more than an educated opinion as to the relationship of the two tumors. Ultimately, clinicopathologic correlation is needed relying on such factors as the initial pathologic stage of the previous tumor, site of the original tumor and new mass, and time interval between tumor presentations. In a patient with a known history of HPV-positive HNSCC, the HPV status can be valuable in resolving the uncertainty of whether a new presentation of SCC represents metastasis versus a new primary. For example, in patients with SCC in the lung, the HPV status of the tu-

HPV-Associated Head and Neck

Carcinoma mor has been shown to be valuable as a means of distinguishing metastatic oropharyngeal HPV-associated HNSCC (including some metastases occurring as late as 8 years after the initial primary presentation) from primary lung SCC [46].

\section{Cytomorphology}

Although any metastatic SCC to the neck with no known primary should be tested for HPV, there are patterns of SCC that are more likely to represent HPV-associated disease. Conventional smoking-related, non-HPVassociated HNSCC is often extensively keratinizing. These cancers are readily recognized by FNA, especially with Pap-stained, alcohol-fixed smears. In contrast, HPV-associated HNSCCs typically present with more challenging aspirates with prominent basaloid, undifferentiated, or cystic features, each of which is considered separately below. These patterns are not mutually exclusive so that the cytologic findings for a given case of HPV-associated HNSCC may show overlapping features including the presence of occasional keratinized tumor cells.

\section{Basaloid Pattern}

The term basaloid refers to cells having a phenotype resembling the basal reserve cell population of stratified epithelia. The scant cytoplasm of these immature cells offers few clues regarding cell lineage. Classification of basaloid neoplasms is dependent on the identification of a component of the tumor that exhibits a greater degree of differentiation characteristic of a specific entity. Thus, a basaloid carcinoma is only recognizable as SCC if either intercellular bridges or keratinization are identifiable. Such findings may be quite focal and demand thorough screening of the aspirate for diagnostic clues. In the absence of these characteristic features, ancillary studies (most commonly immunocytochemistry) are needed to distinguish definitively amongst the various considerations.

Basaloid HPV-associated HNSCC yields cellular aspirates with high-grade cytologic features. Cohesive clusters of basaloid cells as well as loose aggregates of similar appearing cells are present (fig. 1a). Individual cells have scant cytoplasm with intermediate sized hyperchromatic nuclei without prominent nucleoli. The presence of frequent mitoses, single cell necrosis, and nuclear molding may exquisitely mimic small cell carcinoma (fig. 1b). Focal keratinization helps establish the diagnosis of SCC (fig. 1c). Other helpful distinguishing features from small cell carcinoma are the presence of cohesive cellular groups and adenoid cystic-like areas in SCC (fig. 1a, d) [47-50]. 

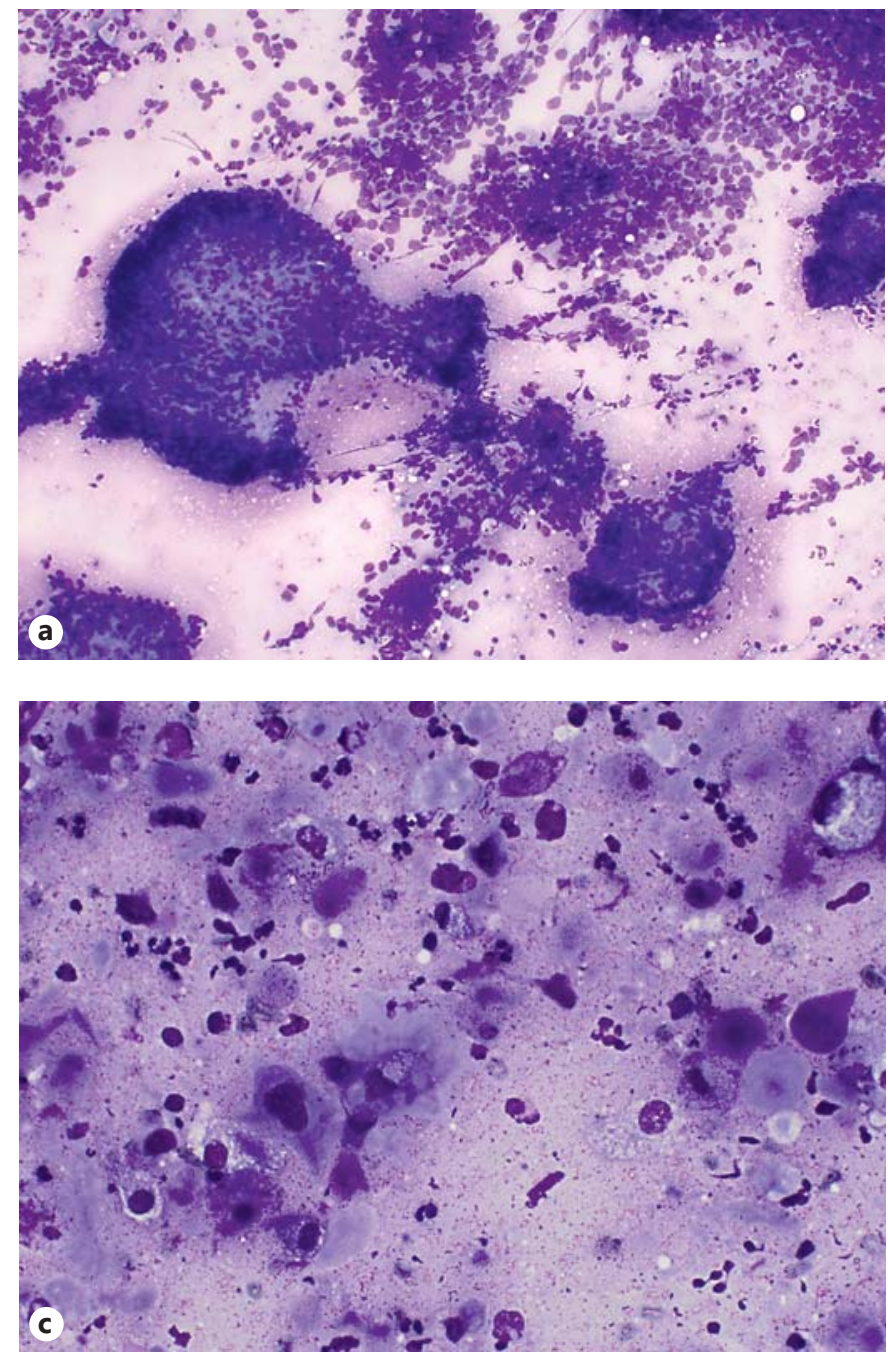

Fig. 1. FNA of HPV-associated HNSCC with a basaloid pattern. a The aspirate is markedly cellular with a mixture of cohesive clusters of cells and loose aggregates of basaloid cells (Romanowsky stain, $\times 100)$. $\mathbf{b}$ The basaloid cells can exquisitely mimic small cell carcinoma with nuclear molding, mitoses, and single cell necrosis

The differential diagnosis of HPV-associated HNSCC with basaloid features inevitably includes a non-HPV-related basaloid HNSCC. This distinction depends on HPV testing and is crucial clinically as non-HPV-related basaloid HNSCC has a worse prognosis than conventional HNSCC rather than the favorable prognosis of HPV-associated HNSCC [31, 32].

Immunohistochemistry is helpful in distinguishing amongst these basaloid neoplasms [51, 52]. SCCs express p63 and CK5/6, while neuroendocrine markers such as synaptophysin and chromogranin identify neuroendocrine carcinomas. p16 expression is sensitive for
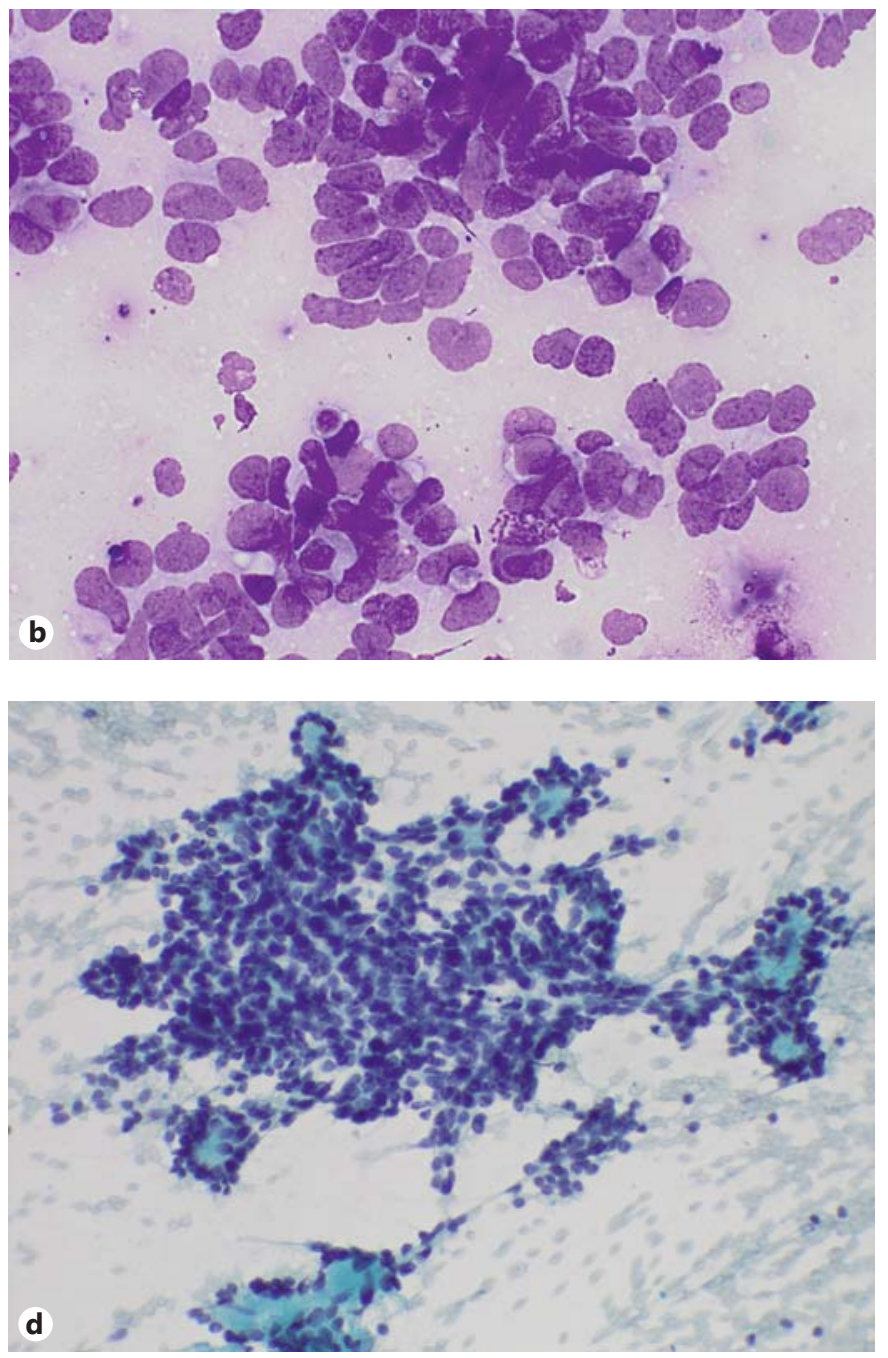

(Romanowsky stain, $\times 400$ ). c A cystic component may be present with a mixed population of inflammatory cells, keratinized cells, and keratin debris (Romanowsky stain, ×400). d Adenoid cystic carcinoma-like areas may be present with acellular stromal spheres present that are surrounded by basaloid cells (Pap stain, $\times 200$ ).

detection of HPV-associated HNSCC, but is also positive in up to $26 \%$ of aggressive basaloid HNSCCs [31]. Of note, p16 is also not a specific surrogate marker for HPV infection in high-grade neuroendocrine carcinomas since activation of the p16 pathway may occur in nonHPV-associated small cell carcinoma [36, 53]. HPV in situ hybridization (ISH) is needed to distinguish HPVassociated HNSCC definitively from these mimics [31, 32].

Basaloid salivary gland neoplasms are also a consideration, primarily the clinically aggressive solid variant of adenoid cystic carcinoma. HPV-associated HNSCC may 

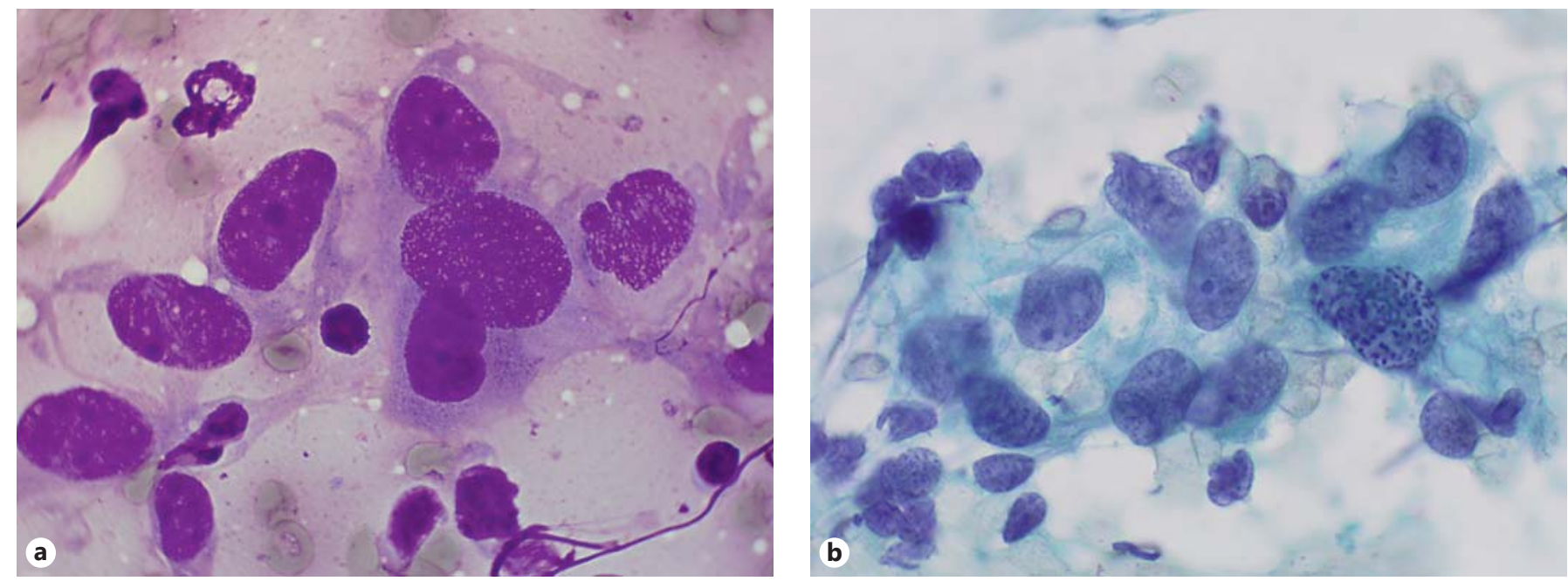

Fig. 2. FNA of HPV-associated HNSCC with an undifferentiated pattern. A syncytial cluster of malignant cells with vesicular chromatin and a single prominent nucleolus is present. Only a few lymphoid cells are present in these images, but may obscure the diagnosis particularly when the malignant cells are dispersed (a Romanowsky stain, $\times 1,000$; b Pap stain, $\times 1,000)$.

exhibit finger-like projections or spherical aggregates of acellular basement membrane material surrounded by basaloid epithelial cells closely mimicking the stromal matrix characteristic of adenoid cystic carcinoma (fig. $1 \mathrm{~d}$ ). If present, squamous differentiation is a valuable distinguishing feature as this finding is absent in adenoid cystic carcinomas [48, 54]. Clinically, presentation of adenoid cystic carcinoma as a neck mass is typically limited to the upper neck with a primary mass in the tail of parotid or submandibular gland. Adenoid cystic carcinoma uncommonly metastasizes to the lower level neck lymph nodes that are most frequently involved by metastatic oropharyngeal HNSCC.

\section{Undifferentiated Pattern}

The undifferentiated pattern of HPV-associated HNSCC is morphologically identical to nasopharyngeal carcinoma (NPC) of the non-keratinizing undifferentiated type $[34,35]$. Both differentiated and undifferentiated non-keratinizing NPCs are also highly associated with an oncogenic virus, Epstein-Barr virus (EBV). Also like HPV-associated HNSCC, NPC frequently presents clinically as lymph node metastasis in the neck; however, the involved lymph nodes are more frequently those in the posterior triangle. The differentiated subtype of NPC has the appearance of a non-keratinizing SCC, while the undifferentiated type is the variant classically described as lymphoepithelial carcinoma. Undifferentiated NPC exhibits an intimate admixture of malignant cells with lymphocytes [55-60]. The malignant cells have scant cytoplasm with large vesicular nuclei having a single prominent nucleolus (fig. 2). The tumor is generally readily recognized as carcinoma when the cells form syncytial aggregates, but when present singly, distinction from lymphoma, particularly Hodgkin's disease or large cell lymphoma, is challenging. Keratin immunostains and the detection of EBV-encoded early mRNAs by ISH support a nasopharyngeal primary $[61,62]$. Similar appearing undifferentiated carcinomas (with variable EBV association) have been described at other sites (including salivary gland), but with the classic presentation of cervical adenopathy a nasopharyngeal primary is most probable. As mentioned above, HPV-associated HNSCC may look identical to undifferentiated NPC (fig. 2) so that initial evaluation of an undifferentiated carcinoma in the neck should include testing for both EBV and HPV. In the United States, the undifferentiated pattern is now more likely to represent an HPV-associated oropharyngeal primary than an EBV-associated NPC, but NPC would be more probable in endemic areas such as Eastern Asia.

\section{Cystic Pattern}

As mentioned earlier, cystic metastatic SCC in a cervical lymph node is sufficiently characteristic that an HPVassociated oropharyngeal primary should be suspected in a patient with this finding [39]. 

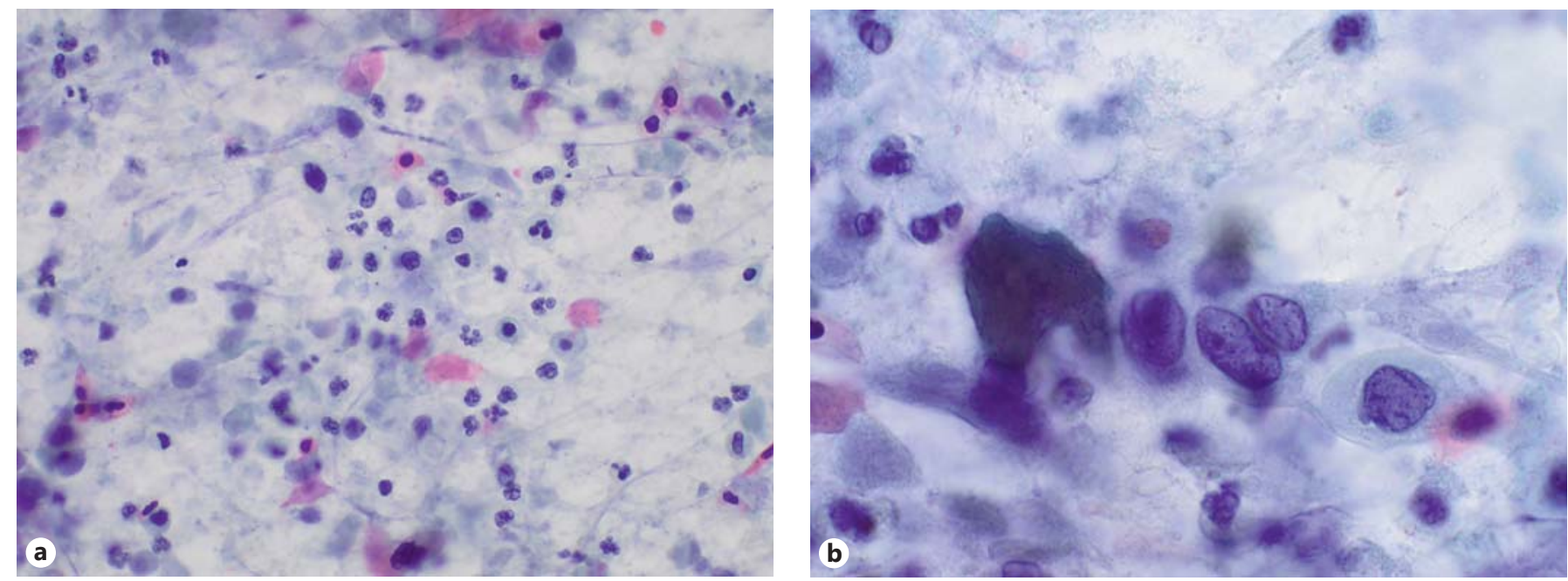

Fig. 3. FNA of HPV-associated HNSCC with a cystic pattern. a Only mildly atypical squamous cells with pyknotic nuclei may be evident in an inflammatory background (Pap stain, $\times 400$ ). b Close examination may be needed to appreciate the presence of a population of pleomorphic squamous cells (Pap stain, $\times 1,000$ ).

Cystic metastases of SCC are treacherous for both the practicing cytopathologist [63] and surgical pathologist and are a significant source of medicolegal claims in the head and neck region due to misdiagnosis as a branchial cleft cyst $[64,65]$. The appearance of such aspirates may be deceptively bland and may in fact lack definitive evidence of malignancy.

As with cysts elsewhere, the presence of numerous macrophages identifies the cystic nature of the lesion. Nucleate and anucleate squames, inflammatory cells, and keratin debris may be seen (fig. 1c, 3a). These are nonspecific findings that may be seen along with a benign lymphoid component in a variety of squamous epitheliallined cysts including developmental cysts (branchial cleft cysts, thyroglossal duct cysts), sporadic lymphoepithelial cysts in the parotid, and in parotid gland benign lymphoepithelial lesions with HIV disease.

It is vital in all such aspirates that the specimen is thoroughly examined for any evidence of squamous atypia in order to not miss the focal presence of cells indicative of SCC (fig. 3b). Even in the absence of such cells, the aspirate should be interpreted with caution, maintaining skepticism toward the diagnosis of a benign developmental cyst in older adults, and having a low threshold for recommending excision for definitive diagnosis. HPV testing of such specimens is also useful in resolving diagnostic uncertainty $[66,67]$.

\section{HPV Detection in Cytologic Material}

In many patients, oropharyngeal HNSCC is treated non-surgically. Therefore, FNA may provide the only opportunity to sample tumor for assessing HPV status. For this reason and for all those stated above, accurate methods for determining HPV status are essential.

The presence of HPV infection can be assessed by a number of different methods in both surgical pathology material and cytologic specimens. HPV testing in surgical pathology material has been extensively studied. The simplest option is the use of immunohistochemistry for p16, a surrogate marker for HPV infection (fig. 4a). p16 is highly sensitive (approaching 100\%) for the presence of HPV infection but with specificity of approximately $80 \%$ [6870]. Overexpression of p16 occurs in a subset of nonHPV-associated SCCs as well as other tumors potentially in the differential diagnosis including small cell carcinoma $[36,53]$ and sinonasal undifferentiated carcinoma [71]. Also problematic is that p16 may be expressed in normal tonsillar crypt epithelium [72] as well as in the benign epithelium within a branchial cleft cyst $[66,67]$ and that there is no universally accepted threshold for p16 positivity.

Direct methods for identifying HPV infection include HPV DNA or RNA detection via polymerase chain reaction (PCR) analysis or ISH. PCR analysis has the advantage of high sensitivity, but also may theoretically detect clinically insignificant infections and is more technically 

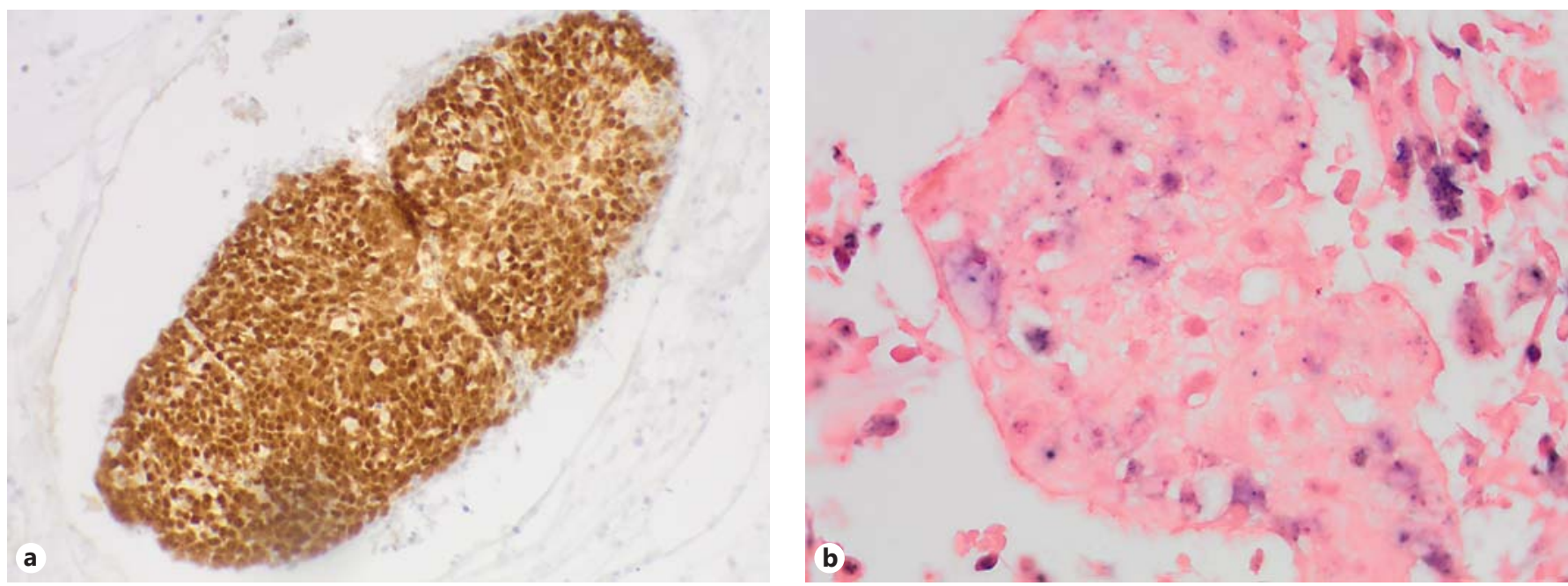

Fig. 4. Special stains for HPV-associated HNSCC. a Immunocytochemistry on cell block material often shows strong nuclear and cytoplasmic staining in all the malignant cells (p16 immunostain, $\times 200$ ). b High-risk HPV DNA ISH signal is often patchy and weak, potentially posing difficulty when limited material is present (HPV ISH, $\times 600)$.

challenging to perform in many laboratories. ISH has slightly lower sensitivity but greater specificity providing the ability to directly visualize the presence of signal in the targeted population of malignant cells. Unfortunately, there is currently no consensus regarding the best method of HPV testing in surgical pathology material. Leading authorities advocate a combination of testing with the sensitivity of p16 and the specificity of high-risk HPV DNA ISH [69]. In our laboratory, we perform these tests in tandem reserving HPV DNA PCR testing for cases that are p16-positive and HPV DNA ISH-negative. The significance of such cases is unclear as there are conflicting data regarding if 16 positivity alone confers a favorable prognosis regardless of whether HPV DNA is detectable $[18,68,73,74]$. A recent study using HPV RNA ISH indicates that many cases in which HPV DNA cannot be detected by ISH still represent HPV infection and are, therefore, indicative of diminished sensitivity of HPV DNA ISH in a subset of cases [75].

The optimal testing method for cytologic specimens is even less established. In a recent study, p16 immunocytochemistry on alcohol-fixed Pap-stained smears correctly localized HNSCC to the oropharynx in $74 \%$ of positive cases, but detected less than $50 \%$ of oropharyngeal primaries [76]. Another study comparing p16 staining in lymph node metastases to matched histologic primaries found $88 \%$ (2 false positives and 1 false negative) concordance in p16 staining for 25 cases of HNSCC [77]. These authors considered a positive p16 result to be staining in 5\% of cells, but noted that their 2 false-positive results would have been negative with a $10 \%$ threshold. In FNA cell blocks, both p16 immunocytochemistry and HPV DNA ISH have been successful in determining site of tumor origin in SCC cervical lymph node metastases $[61,78]$. With adequate cell block material, testing may be performed in the same manner as on surgical pathology material (fig. 4). However, the sparse quantity of material often encountered in cell block preparations is potentially challenging both for interpretation of p16 immunocytochemistry and HPV ISH. The lack of a uniformly accepted threshold for defining a p16-positive result is problematic. In most instances, HPV infection is reflected by diffuse nuclear and cytoplasmic p16 immunoreactivity (fig. 4a). In surgical pathology material, thresholds ranging from 5 to $70 \%$ of positive cells have been advocated as constituting a p16-positive result $[69,77]$. Conversely, in cytology series, any p16 staining has been interpreted as a positive result $[69,78]$. Since p16 immunostaining may occur in the benign epithelium of a branchial cleft cyst $[66,67]$, a low threshold risks falsely positive p16 results. As for HPV DNA ISH (fig. 4b), detection of HPV DNA is commonly patchy in histologic material [72] increasing the likelihood of a falsely negative result in limited cell block material.

DNA ISH on alcohol-fixed smears has also been used successfully for HPV detection in HNSCC $[79,80]$ as has 
PCR [81]. Recently, detection methods previously validated for HPV cervical Pap testing including proprietary commercial methods such as Hybrid Capture II [82] and Cervista [83] have successfully detected HPV DNA in HNSCC using archival air-dried, alcohol-fixed, and liquid-based preparations. The most rigorous testing to date has been a feasibility test using Hybrid Capture II on cytologic material obtained from surgically resected HPVassociated HNSCC [82]. In this study, Hybrid Capture II proved to have high sensitivity and specificity with rapid turnaround of testing, easy acquisition of adequate material for testing, easy interpretation of the testing result, and low cost.
With the current absence of consensus guidelines for HPV detection in cytologic material, each laboratory should select and optimize testing according to available resources and clinical demands. It should be emphasized that critical decision-making for treatment, clinical trial enrollment, and prognosis may rest solely on the determination of the HPV status of the patient's tumor. Accordingly, every effort should be made to validate whatever testing method is used within an individual laboratory to provide the highest possible level of quality assurance.

\section{References}

1 Chaturvedi AK, Engels EA, Anderson WF, Gillison ML: Incidence trends for human papillomavirus-related and -unrelated oral squamous cell carcinomas in the United States. J Clin Oncol 2008;26:612-619.

$\checkmark 2$ Sturgis EM, Cinciripini PM: Trends in head and neck cancer incidence in relation to smoking prevalence: an emerging epidemic of human papillomavirus-associated cancers? Cancer 2007;110:1429-1435.

-3 Gillison ML, Koch WM, Capone RB, Spafford M, Westra WH, Wu L, Zahurak ML, Daniel RW, Viglione M, Symer DE, Shah KV, Sidransky D: Evidence for a causal association between human papillomavirus and a subset of head and neck cancers. J Natl Cancer Inst 2000;92:709-720.

4 Paz IB, Cook N, Odom-Maryon T, Xie Y, Wilczynski SP: Human papillomavirus (HPV) in head and neck cancer. An association of HPV16 with squamous cell carcinoma of Waldeyer's tonsillar ring. Cancer 997;79:595604.

5 Marur S, D’Souza G, Westra WH, Forastiere AA: HPV-associated head and neck cancer: a virus-related cancer epidemic. Lancet Oncol 2010;11:781-789.

-6 Hammarstedt L, Lindquist D, Dahlstrand H, Romanitan M, Dahlgren LO, Joneberg J, Creson N, Lindholm J, Ye W, Dalianis T, MunckWikland E: Human papillomavirus as a risk factor for the increase in incidence of tonsillar cancer. Int J Cancer 2006;119:2620-2623.

7 Cohan DM, Popat S, Kaplan SE, Rigual N, Loree T, Hicks WL Jr: Oropharyngeal cancer: current understanding and management. Curr Opin Otolaryngol Head Neck Surg 2009; 17:88-94.

8 Gillison ML, D’Souza G, Westra W, Sugar E, Xiao W, Begum S, Viscidi R: Distinct risk factor profiles for human papillomavirus type 16-positive and human papillomavirus type 16-negative head and neck cancers. J Natl Cancer Inst 2008;100:407-420.
9 Vidal L, Gillison ML: Human papillomavirus in HNSCC: recognition of a distinct disease type. Hematol Oncol Clin North Am 2008;22: 1125-1142, vii.

$\rightarrow 10$ Kreimer AR, Alberg AJ, Daniel R, Gravitt PE, Viscidi R, Garrett ES, Shah KV, and Gillison ML: Oral human papillomavirus infection in adults is associated with sexual behavior and HIV serostatus. J Infect Dis 2004;189:686698.

11 Gillison ML, Broutian T, Pickard RK, Tong ZY, Xiao W, Kahle L, Graubard BI, Chaturvedi AK: Prevalence of oral HPV infection in the United States, 2009-2010. JAMA 2012;307: 693-703.

12 Hernandez BY, Wilkens LR, Zhu X, Thompson P, McDuffie K, Shvetsov YB, Kamemoto LE, Killeen J, Ning L, Goodman MT: Transmission of human papillomavirus in heterosexual couples. Emerg Infect Dis 2008;14: 888-894.

13 Castellsagué X, Muñoz N: Cofactors in human papillomavirus carcinogenesis: role of parity, oral contraceptives, and tobacco smoking. J Natl Cancer Inst Monogr 2003;31: 20-28.

14 Markowitz LE, Sternberg M, Dunne EF, McQuillan G, Unger ER: Seroprevalence of human papillomavirus types $6,11,16$, and 18 in the United States: National Health and Nutrition Examination Survey 2003-2004. J Infect Dis 2009;200:1059-1067.

-15 Safaeian M, Porras C, Schiffman M, Rodriguez AC, Wacholder S, Gonzalez P, Quint W, van Doorn LJ, Sherman ME, Xhenseval V, Herrero R, Hildesheim A, Costa Rican Vaccine Trial Group: Epidemiological study of anti-HPV16/18 seropositivity and subsequent risk of HPV16 and - 18 infections. J Natl Cancer Inst 2010;102:1653-1662.
16 Wiest T, Schwarz E, Enders C, Flechtenmacher C, Bosch FX: Involvement of intact HPV16 E6/E7 gene expression in head and neck cancers with unaltered p53 status and perturbed pRb cell cycle control. Oncogene 2002;21: 1510-1517.

17 Andl T, Kahn T, Pfuhl A, Nicola T, Erber R, Conradt C, Klein W, Helbig M, Dietz A, Weidauer H, Bosch FX: Etiological involvement of oncogenic human papillomavirus in tonsillar squamous cell carcinomas lacking retinoblastoma cell cycle control. Cancer Res 1998; 58:5-13.

18 Ang KK, Harris J, Wheeler R, Weber R, Rosenthal DI, Nguyen-Tân PF, Westra WH, Chung CH, Jordan RC, Lu C, Kim H, Axelrod R, Silverman CC, Redmond KP, Gillison ML: Human papillomavirus and survival of patients with oropharyngeal cancer. N Engl J Med 2010;363:24-35.

-19 D’Souza G, Kreimer AR, Viscidi R, Pawlita M, Fakhry C, Koch WM, Westra WH, Gillison ML: Case-control study of human papillomavirus and oropharyngeal cancer. N Engl J Med 2007;356:1944-1956.

20 Fakhry C, Westra WH, Li S, Cmelak A, Ridge JA, Pinto H, Forastiere A, Gillison ML: Improved survival of patients with human papillomavirus-positive head and neck squamous cell carcinoma in a prospective clinical trial. J Natl Cancer Inst 2008; 100:261-269.

21 Kies MS, Holsinger FC, Lee JJ, William WN Jr, Glisson BS, Lin HY, Lewin JS, Ginsberg LE, Gillaspy KA, Massarelli E, Byers L, Lippman SM, Hong WK, El-Naggar AK, Garden AS, Papadimitrakopoulou V: Induction chemotherapy and cetuximab for locally advanced squamous cell carcinoma of the head and neck: results from a phase II prospective trial. J Clin Oncol 2010;28:8-14. 
-22 Lassen P, Eriksen JG, Hamilton-Dutoit S, Tramm T, Alsner J, Overgaard J: Effect of HPV-associated p16INK4A expression on response to radiotherapy and survival in squamous cell carcinoma of the head and neck. J Clin Oncol 2009;27:1992-1998.

-23 Lassen P, Eriksen JG, Hamilton-Dutoit S, Tramm T, Alsner J, Overgaard J, Danish Head and Neck Cancer Group (DAHANCA): HPV-associated p16 expression and response to hypoxic modification of radiotherapy in head and neck cancer. Radiother Oncol 2010; 94:30-35.

24 Lassen P, Eriksen JG, Krogdahl A, Therkildsen MH, Ulhøi BP, Overgaard M, Specht L, Andersen E, Johansen J, Andersen LJ, Grau C, Overgaard J, Danish Head and Neck Cancer Group (DAHANCA): The influence of HPVassociated p16 expression on accelerated fractionated radiotherapy in head and neck cancer: evaluation of the randomised DAHANCA 6\&7 trial. Radiother Oncol 2011;100: 49-55.

-25 Posner MR, Lorch JH, Goloubeva O, Tan M, Schumaker LM, Sarlis NJ, Haddad RI, Cullen $\mathrm{KJ}$ : Survival and human papillomavirus in oropharynx cancer in TAX 324: a subset analysis from an international phase III trial. Ann Oncol 2011;22:1071-1077.

-26 Rischin D, Young RJ, Fisher R, Fox SB, Le QT, Peters LJ, Solomon B, Choi J, O'Sullivan B, Kenny LM, McArthur GA: Prognostic significance of p16INK4A and human papillomavirus in patients with oropharyngeal cancer treated on TROG 02.02 phase III trial. J Clin Oncol 2010;28:4142-4148.

$\checkmark 27$ Worden FP, Kumar B, Lee JS, Wolf GT, Cordell KG, Taylor JM, Urba SG, Eisbruch A, Teknos TN, Chepeha DB, Prince ME, Tsien CI, D'Silva NJ, Yang K, Kurnit DM, Mason HL, Miller TH, Wallace NE, Bradford CR, Carey TE: Chemoselection as a strategy for organ preservation in advanced oropharynx cancer: response and survival positively associated with HPV16 copy number. J Clin Oncol 2008;26:3138-3146.

28 Chung CH, Schwartz DL: Impact of HPV-related head and neck cancer in clinical trials: opportunity to translate scientific insight into personalized care. Otolaryngol Clin North Am 2012;45:795-806.

-29 El Mofty SK, Lu DW: Prevalence of human papillomavirus type 16 DNA in squamous cell carcinoma of the palatine tonsil, and not the oral cavity, in young patients: a distinct clinicopathologic and molecular disease entity. Am J Surg Pathol 2003;27:1463-1470.

30 Barnes L, Eveson JW, Reichart P, Sidransky D (eds): Pathology and Genetics of Head and Neck Tumours. Lyon, IARC Press, 2007.

- 31 Begum S, Westra WH: Basaloid squamous cell carcinoma of the head and neck is a mixed variant that can be further resolved by HPV status. Am J Surg Pathol 2008;32:1044-1050.
Chernock RD, Lewis JS Jr, Zhang Q, El-Mofty SK: Human papillomavirus-positive basaloid squamous cell carcinomas of the upper aerodigestive tract: a distinct clinicopathologic and molecular subtype of basaloid squamous cell carcinoma. Hum Pathol 2010;41: 1016-1023.

33 Jo VY, Mills SE, Stoler MH, Stelow EB: Papillary squamous cell carcinoma of the head and neck: frequent association with human papillomavirus infection and invasive carcinoma. Am J Surg Pathol 2009;33:1720-1724.

34 Carpenter DH, El-Mofty SK, Lewis JS Jr: Undifferentiated carcinoma of the oropharynx: a human papillomavirus-associated tumor with a favorable prognosis. Mod Pathol 2011; 24:1306-1312.

35 Singhi AD, Stelow EB, Mills SE, Westra WH. Lymphoepithelial-like carcinoma of the oropharynx: a morphologic variant of HPV-related head and neck carcinoma. Am J Surg Pathol 2010;34:800-805.

36 Bishop JA, Westra WH: Human papillomavirus-related small cell carcinoma of the oropharynx. Am J Surg Pathol 2011;35:16791684.

37 Kraft S, Faquin WC, Krane JF: HPV-associated neuroendocrine carcinoma of the oropharynx: a rare new entity with potentially aggressive clinical behavior. Am J Surg Pathol 2012;36:321-330.

38 Thompson LD, Heffner DK: The clinical importance of cystic squamous cell carcinomas in the neck: a study of 136 cases. Cancer 1998; 82:944-956.

-39 Goldenberg D, Begum S, Westra WH, Khan Z, Sciubba J, Pai SI, Califano JA, Tufano RP, Koch WM: Cystic lymph node metastasis in patients with head and neck cancer: an HPV associated phenomenon. Head Neck 2008;30: 898-903.

40 Fakhry C, Rosenthal BT, Clark DP, Gillison ML: Associations between oral HPV16 infection and cytopathology: evaluation of an oropharyngeal 'Pap-test equivalent' in high-risk populations. Cancer Prev Res 2011;4:13781384.

41 Jarboe EA, Willis M, Bentz B, Buchmann L, Hunt J, Ellis G, Layfield L: Detection of human papillomavirus using Hybrid Capture II in oral brushings from patients with oropharyngeal squamous cell carcinoma. Am J Clin Pathol 2011;135:766-769.

42 Lingen MW: Brush-based cytology screening in the tonsils and cervix: there is a difference! Cancer Prev Res 2011;4:1350-1352.

43 Begum S, Gillison ML, Ansari-Lari MA, Shah K, Westra WH: Detection of human papillomavirus in cervical lymph nodes: a highly effective strategy for localizing site of tumor origin. Clin Cancer Res 2003;9:6469-6475.

44 De Braud F, Sarraf M: Diagnosis and management of squamous cell carcinoma of unknown primary tumor site of the neck. Semin Oncol 1993;20:273-278.
45 Best SR, Niparko KJ, Pai SI: Biology of human papillomavirus infection and immune therapy for HPV-related head and neck cancers. Otolaryngol Clin North Am 2012;45:807822.

46 Bishop JA, Ogawa T, Chang X, Illei PB, Gabrielson E, Pai SI, Westra WH: HPV analysis in distinguishing second primary tumors from lung metastases in patients with head and neck squamous cell carcinoma. Am J Surg Pathol 2012;36:142-148.

47 Banks ER, Frierson HF Jr, Covell JL: Fineneedle aspiration cytologic findings in metastatic basaloid squamous cell carcinoma of the head and neck. Acta Cytol 1992;36:126131.

48 Gilcrease MZ, Guzman-Paz M: Fine-needle aspiration of basaloid squamous carcinoma: a case report with review of differential diagnostic considerations. Diagn Cytopathol 1998;19:210-215.

49 Marks RA, Cramer HM, Wu HH: Fine-needle aspiration cytology of basaloid squamous cell carcinoma and small cell carcinoma - a comparison study. Diagn Cytopathol 2013;41:8184.

50 Wain SL, Kier R, Vollmer RT, Bossen EH: Basaloid-squamous carcinoma of the tongue, hypopharynx, and larynx: report of 10 cases. Hum Pathol 1986;17:1158-1166.

51 Wu M, Wang B, Gil J, Sabo E, Miller L, Gan L, Burstein DE: p63 and TTF-1 immunostaining. A useful marker panel for distinguishing small cell carcinoma of lung from poorly differentiated squamous cell carcinoma of lung. Am J Clin Pathol 2003;119:696-702.

52 Zhang H, Liu J, Cagle PT, Allen TC, Laga AC, Zander DS: Distinction of pulmonary small cell carcinoma from poorly differentiated squamous cell carcinoma: an immunohistochemical approach. Mod Pathol 2005; 18:111118.

53 Yuan J, Knorr J, Altmannsberger M, Goeckenjan G, Ahr A, Scharl A, Strebhardt K: Expression of p16 and lack of pRB in primary small cell lung cancer. J Pathol 1999;189:358362.

54 Madur BP, Jambhekar NA: Basaloid squamous carcinoma simulating adenoid cystic carcinoma: diagnostic dilemma. Oral Oncol 2006;42:227-230.

55 Chan MK, McGuire LJ, Lee JC: Fine-needle aspiration cytodiagnosis of nasopharyngeal carcinoma in cervical lymph nodes. A study of 40 cases. Acta Cytol 1989;33:344-350.

56 Grenko RT, Shabb NS: Metastatic nasopharyngeal carcinoma: cytologic features of 18 cases. Diagn Cytopathol 1991;7:562-566.

57 Jayaram G, Swain M, Khanijow V, Jalaludin MA: Fine-needle aspiration cytology of metastatic nasopharyngeal carcinoma. Diagn $\mathrm{Cy}-$ topathol 1998;19:168-172. 
58 Kollur SM, El Hag IA: Fine-needle aspiration cytology of metastatic nasopharyngeal carcinoma in cervical lymph nodes: comparison with metastatic squamous cell carcinoma, and Hodgkin's and non-Hodgkin's lymphoma. Diagn Cytopathol 2003;28:18-22.

59 Mohanty SK, Dey P, Ghoshal S, Saikia UN: Cytologic features of metastatic nasopharyngeal carcinoma. Diagn Cytopathol 2002;27: 340-342.

-60 Viguer JM, Jiménez-Heffernan JA, LópezFerrer P, Banaclocha M, Vicandi B: Fine-needle aspiration cytology of metastatic nasopharyngeal carcinoma. Diagn Cytopathol 2005; 32:233-237.

-61 Jannapureddy S, Cohen C, Lau S, Beitler JJ, Siddiqui MT: Assessing for primary oropharyngeal or nasopharyngeal squamous cell carcinoma from fine-needle aspiration of cervical lymph node metastases. Diagn Cytopathol 2010;38:795-800

62 Lee WY, Hsiao JR, Jin YT, Tsai ST: EpsteinBarr virus detection in neck metastases by insitu hybridization in fine-needle aspiration cytologic studies: an aid for differentiating the primary site. Head Neck 2000;22:336-340.

-63 Ustün M, Risberg B, Davidson B, Berner A: Cystic change in metastatic lymph nodes: a common diagnostic pitfall in fine-needle aspiration cytology. Diagn Cytopathol 2002;27: 387-392.

64 Troxel D: Diagnostic errors in surgical pathology uncovered by a review of malpractice claims. VI. Urinary bladder and branchial cleft cyst. Int J Surg Pathol 2001;9:227-229.

65 Troxel DB: Trends in pathology malpractice claims. Am J Surg Pathol 2012;36:e1-e5.

66 Cao D, Begum S, Ali SZ, Westra WH: Expression of p16 in benign and malignant cystic squamous lesions of the neck. Hum Pathol 2010;41:535-539.

67 Pai RK, Erickson J, Pourmand N, Kong CS: p16(INK4A) immunohistochemical staining may be helpful in distinguishing branchial cleft cysts from cystic squamous cell carcinomas originating in the oropharynx. Cancer 2009;117:108-119.
68 Schache AG, Liloglou T, Risk JM, Filia A, Jones TM, Sheard J, Woolgar JA, Helliwell TR, Triantafyllou A, Robinson M, Sloan P, Harvey-Woodworth C, Sisson D, Shaw RJ: Evaluation of human papilloma virus diagnostic testing in oropharyngeal squamous cell carcinoma: sensitivity, specificity, and prognostic discrimination. Clin Cancer Res 2011; 17:6262-6271.

69 Singhi AD, Westra WH. Comparison of human papillomavirus in situ hybridization and p16 immunohistochemistry in the detection of human papillomavirus-associated head and neck cancer based on a prospective clinical experience. Cancer 2010;116:2166-2173.

Smeets SJ, Hesselink AT, Speel EJ, Haesevoets A, Snijders PJ, Pawlita M, Meijer CJ, Braakhuis BJ, Leemans CR, Brakenhoff RH: A novel algorithm for reliable detection of human papillomavirus in paraffin-embedded head and neck cancer specimen. Int J Cancer 2007;121: 2465-2472.

71 Wadsworth B, Bumpous JM, Martin AW, Nowacki MR, Jenson AB, Farghaly H: Expression of p16 in sinonasal undifferentiated carcinoma without associated human papillomavirus. Head Neck Pathol 2011;5:349-354.

72 Begum S, Cao D, Gillison M, Zahurak M, Westra WH: Tissue distribution of human papillomavirus 16 DNA integration in patients with tonsillar carcinoma. Clin Cancer Res 2005;11:5694-5699.

73 Lewis JS Jr, Thorstad WL, Chernock RD, Haughey BH, Yip JH, Zhang Q, El-Mofty SK p16-positive oropharyngeal squamous cell carcinoma: an entity with a favorable prognosis regardless of tumor HPV status. Am J Surg Pathol 2010;34:1088-1096.

74 Perrone F, Gloghini A, Cortelazzi B, Bossi P, Licitra L, Pilotti S: Isolating p16-positive/ HPV-negative oropharyngeal cancer: an effort worth making. Am J Surg Pathol 2011;35: 774-777.

75 Bishop JA, Ma XJ, Wang H, Luo Y, Illei PB, Begum S, Taube JM, Koch WM, Westra WH: Detection of transcriptionally active high-risk HPV in patients with head and neck squamous cell carcinoma as visualized by a novel E6/E7 mRNA in situ hybridization method. Am J Surg Pathol 2012;36:1874-1882.
6 Grimes R, Garcia-Buitrago MT, Jorda M, Ganjei-Azar P, Ferrell A, Gomez-Fernandez C: p16INKa immunocytochemistry in fineneedle aspiration cytology smears of metastatic head and neck squamous cell carcinoma. Acta Cytol 2013;57:33-37.

77 Jakscha J, Zlobec I, Storck C, Obermann EC, Tornillo L, Terracciano LM, Fischer CA: The clinical impact of p16 status in fine-needle aspirates of cervical lymph node metastasis of head and neck squamous cell carcinomas. Eur Arch Otorhinolaryngol 2012, E-pub ahead of print.

78 Begum S, Gillison ML, Nicol TL, Westra WH: Detection of human papillomavirus-16 in fine-needle aspirates to determine tumor origin in patients with metastatic squamous cell carcinoma of the head and neck. Clin Cancer Res. 2007;13:1186-1191.

79 Umudum H, Rezanko T, Dag F, Dogruluk T: Human papillomavirus genome detection by in situ hybridization in fine-needle aspirates of metastatic lesions from head and neck squamous cell carcinomas. Cancer 2005; 105 : 171-177.

80 Zhang MQ, El-Mofty SK, Dávila RM: Detection of human papillomavirus-related squamous cell carcinoma cytologically and by in situ hybridization in fine-needle aspiration biopsies of cervical metastasis: a tool for identifying the site of an occult head and neck primary. Cancer 2008;114:118-123.

81 Barwad A, Sood S, Gupta N, Rajwanshi A, Panda N, Srinivasan R: Human papilloma virus-associated head and neck cancer: a PCRbased study. Diagn Cytopathol 2012;40:893897.

-82 Bishop JA, Maleki Z, Valsamakis A, Ogawa T, Chang X, Pai SI, Westra WH: Application of the Hybrid Capture II assay to squamous cell carcinomas of the head and neck: a convenient liquid-phase approach for the reliable determination of human papillomavirus status. Cancer Cytopathol 2012;120:1825.

83 Solomides CC, Bibbo M, Wang ZX: Assessment of fine-needle aspiration specimen adequacy for high-risk HPV detection and genotyping in oropharyngeal squamous cell carcinoma. Acta Cytol 2012;56:196-198. 